\title{
Milletvekili Adaylarının Seçim Kampanyalarının Finansmanı: 2011 Genel Seçimlerine İlişkin Bir İnceleme
}

\author{
Financing Electoral Campaigns of Parliamentary Candidates: An Analysis about 2011 \\ General Elections
}

Çağatay ORÇUN ${ }^{1}$, Mehmet Can DEMIRTAŞ²

\begin{abstract}
ÖZET
Milletvekilliği, temelde halkın kendi iradesiyle yönetilme hakkını devrettiği bir statüdür. Tüm seçim dönemlerinde siyasi partiler ve adaylar maksimum oy seviyesine ulaşmak için belirli düzeylerde kampanya harcaması gerçekleştirirler. Siyasetin finansmanı kavramının büyük bir kısmını oluşturan bu kavram; hazine yardımları, aidatlar, bağışlar ve çeşitli organizasyonlardan sağlanan gelirlerden oluşmaktadır. Milletvekili olmak isteyen kişilerde seçim dönemlerinde daha iyi tanıtım faaliyetleri gerçekleştirmek için mümkün olduğu ölçüde ek fon yaratma çabası sergilemektedir. Bu açıdan, her milletvekili adayı bir dizi finansal kararlar verir ve finans perspektifine göre, yatırımc benzeri bir karar sürecine dahil olur.
\end{abstract}

Bu çalışmanın amacı, adayların kişisel kampanya bütçelerini tanımlamak ve finans bakış açısı ile seçimleri kazanmak için risk alan ya da almayan bir birey gibi hareket edip etmediklerini ortaya çıkartmaktır. Bu amaca yönelik olarak İzmir Ili'nde seçime katılan on dört siyasi partinin milletvekili adaylarına ve bağımsız adaylara yönelik bir anket uygulaması gerçekleştirilmiş ve elde edilen bulgular değerlendirilmiştir.

Anahtar Kelimeler: Milletvekilleri, siyasetin finansmanı, risk alma, finansal tercih.

\section{GíRiş}

Modern ekonomi bilimi rasyonel insan varsayımına dayanır. Ancak son dönemlerde davranışsal finans kapsamında yapılan çalışmalarda, yatırımcıların karar verme süreçlerinde rasyonel davranma varsayımına uygun olmayan hareket tarzları dikkat çekmektedir. Bu durum beraberinde rasyonel davranma varsayımını temel alan birçok finans teorisinin de yetersiz kalmasına sebep olmaktadır.

Bu boşluğun giderilmesi noktasında ortaya çıkan "davranışsal finans" kavramı, bilişsel, duygusal ve diğer birtakım psikolojik faktörlerin bireyleri nasıl etkilediklerini ve onları nasıl rasyonellikten uzaklaştırdığını, ya da diğer bir ifade ile nasıl sınırlı rasyonel hale geldiklerini incelemesi bakımından önem arz etmektedir.

\begin{abstract}
Being a member of parliament is essentially a status where voters transfer their right of management by own will. During election periods, political parties and parliamentary candidates take in hand a specific amount of campaign spending to reach a maximum level of votes. That concept, which constitutes a large part of the concept of political finance, consists of treasury grands, fees, donations and income from various organizations. Individuals, who are willing to be a member of parliament, also demonstrate effort of raising additional funds as much as possible for performing better promotion activities. In this regard, each parliamentary candidate gives series of financial decisions and engages into a decision process like an investor according to a finance perspective.
\end{abstract}

The aim of this article is to determine the private campaign budgets of the candidates and to reveal whether they act as a risk taker or not to win the election from the financial viewpoint. For this purpose a survey is conducted to parliamentary candidates including 14 political parties and independents which stand for election in Izmir and the findings are analyzed.

Keywords: Member of parliament, political finance, risk taking, financial choice.

Bireyleri karar alma süreçlerinde etkileyen önemli faktörlerden biri; risk algılarıdır. Planlanan ya da tahminlenenle gerçekleşen arasındaki olumlu ya da olumsuz fark olarak tanımlanan risk kavramına (Bolak, 2004) verdikleri tepki açısından bireyler üç farklı şekilde gruplandırılabilir. Bunlardan ilki, riskten kaçan bireylerdir. Genel olarak riski sevmeyen bu tip bireyler, getirileri önceden belirli olan iki yatırım arasından daha az riskli olanı tercih ederler. Bir diğeri, riske karşı kayıtsız bireylerdir. Bu tip bireyler, riski dikkate almayan, risk ve getiri arasında kayıtsız kalan bireylerdir. Son grup ise, riski seven birey tipidir. Riski seven bireyler için, kararın beklenen faydası, karar vermemenin beklenen faydasından daha büyüktür ve genellikle bu tip karar vericiler servetlerinde bir artış

\footnotetext{
' Araş. Gör., Dokuz Eylül Üniversitesi, İktisadi ve İdari Bilimler Fakültesi, İşletme Bölümü, cagatay.orcun@deu.edu.tr
}

${ }^{2}$ Araş. Gör., Dokuz Eylül Üniversitesi, İktisadi ve İdari Bilimler Fakültesi, İşletme Bölümü, can.demirtas@deu.edu.tr 
söz konusu olduğu anda, buna bağlı olarak portföylerindeki riskli varlıkların oranını da yükseltirler.

$\mathrm{Bu}$ çalışmanın amacı, milletvekili adaylarının, seçim dönemlerinde seçim kampanya bütçelerinin belirlenmesi ve seçimi kazanmak adına, risklerini arttırıp arttıramayacaklarının analiz edilmesidir. Bu kapsamda çalışma dört bölümden oluşmaktadır. Birinci bölümde "siyasetin finansmanı" kavramı açılanmış, bu kapsamda siyasi partilerin hangi amaçlara yönelik olarak fona intiyaç duydukları ve bu fonları hangi kaynaklardan tedarik ettikleri incelenmiştir. Çalışmanın ikinci ve üçüncü bölümünde araştırmanın amacı, verileri, kapsamı ve yöntemi açıklanmıştır. Son bölümde ise, elde edilen bulgular değerlendirilmiştir.

\section{SIYASETIN FINANSMANI}

2820 sayılı Siyasi Partiler Kanununa göre; "Anayasa ve kanunlara uygun olarak; milletvekili ve mahalli idareler seçimleri yoluyla, tüzük ve programlarında belirlenen görüşleri doğrultusunda çalışmaları ve açık propagandaları ile milli iradenin oluşmasını sağlayarak demokratik bir Devlet ve toplum düzeni içinde ülkenin çağdaş medeniyet seviyesine ulaşması amacını güden ve ülke çapında faaliyet göstermek üzere teşkilatlanan tüzel kişiliğe sahip kuruluşlar" olarak tanımlanan siyasi partiler, demokratik hayatın vazgeçilmez unsurlarından biridir.

1980 'li yıllardan günümüze kurulan partilerin sayısındaki ciddi artış, beraberinde siyasi rekabet ortamının oluşmasına zemin hazırlamıştır. Bu rekabet ortamında avantajı "parayla" yaratmayı düşünen partilerin, teknolojik yeniliklerinde etkisi ile ekonomik ve finansal yapılarında ciddi bozulmalar meydana gelmektedir. Özellikle seçim dönemlerinde, "ne kadar fazla tanıtım yapılırsa o kadar fazla oy alınır" düşüncesi partilerin harcama kalemlerinde ciddi artışlara sebep olması ve bu harcama kalemlerinin parti gelir kaynakları tarafından karşılanamayacak düzeylere ulaşması, partileri alternatif gelir kaynakları arayışına itmektedir. Bu noktada, partilerin gelir kaynaklarının yanında adaylarında ek fon yaratma çabaları seçim kampanyalarının finansmanında önemli bir yere sahiptir.

"Siyasetin finansmanı" olarak ifade edilen kavram, dar anlamda, seçim dönemlerinde parti ve adayların ya da diğer bir ifade ile seçim kampanyasının finansmanı olarak düşünülse de, geniş anlamda, seçim ve seçim zamanları dışında kalan dönemlerde siyasi partilerin varlıklarını ve faaliyetlerini devam ettirebilmeleri için fona gereksinim duymalarını ifade etmektedir (Duschinsky, 2002).
Fisher ve Eisenstadt (2004) benzer şekilde birbirleri ile rekabet halinde olan siyasi partilerin üç sebepten dolayı fona ihtiyaç duyduklarını belirtmişlerdir. Bu sebepler; seçim kampanyalarını sürdürmek, seçime uygun örgütler kurmak ve parti liderlerine ve temsilcilerine araştırma ve diğer konularda yardımcı olmaktır.

Heidenheimer 1963 yılında yayınladığı "Karşılaştırmalı Parti Finansmanı" başlıklı çalışmasında, siyasi partilerin finansmanında dört tarihsel aşamanın mevcut olduğunu belirtmiştir. Tarihsel evrimi ve siyasi gelişmeleri gözönüne alan bu modele göre, ilk aşamada siyasal sürece katılan sınırlı sayıda seçmen bulunmaktadır ve nüfus başına siyasi kampanya maliyeti oldukça düşüktür. İkinci aşamada, gerek iletişim tekniklerinde meydana gelen gelişmeler, gerekse de kampanyaları yöneten profesyonellerin yaygınlaşmasıyla kampanya giderleri artmış ve partilerin finansmanı, üzerinde çalışıması gereken bir sorun olarak görülmeye başlamıştır. Üçüncü aşamada, gönüllü ya da kurumsal nitelikteki etkinlikler nedeniyle giderler azalmaktadır. Son aşamada ise, siyasi propaganda için gerekli olan maddi kaynaklarla gönüllü çalışma ve kurumsal destek tarafından sağlanan olanaklar arasındaki uçurum nedeniyle maliyetler artmış ve giderlerin karşılanmasında büyük zorluklar oluşmuştur (Özyavuz, 2007).

Siyasi partiler, amaçlarına aykırı olmayacak şekilde faaliyetlerine devam edebilmek ve özellikle seçim dönemlerinde, propaganda faaliyetlerini en iyi şekilde yerine getirebilmek için gelir kaynaklarına intiyaç duyarlar. Türkiye'de siyasi partilerin gelir kaynaklarının neler olabileceği 2820 sayılı Siyasi Partiler Kanununda belirlenmiştir. Kanuna göre siyasi partiler aşağıda belirtilen gelirleri elde edilebilirler;

- Parti üyelerinden alınacak giriş aidatı ile üyelik aidatı,

- Partili milletvekillerinden alınacak milletvekilliği aidatı,

- Milletvekili, belediye başkanlığı, belediye meclis üyeliği ve il genel meclis üyeliği aday adaylarından alınacak özel aidat,

- Parti bayrağı, flaması, rozeti ve benzeri rumuzların satışından sağlanacak gelirler,

- Parti yayınlarının satış bedelleri,

- Üye kimlik kartlarının ve parti defter, makbuz ve kağıtlarının sağlanması karşılığında alınacak paralar,

- Partice tertiplenen balo, eğlence ve konser faaliyetlerinden sağlanacak gelirler, 
- Parti mal varlığından elde edilecek gelirler,

- Bağışlar,

- Devletçe yapılan yardımlar.

Siyasi partilerin faaliyetlerini yürütebilmek ve buna bağlı olarak iktidara gelebilmek için gerekli olan maddi kaynak, öncelikle topladıkları "aidatlar" ve "bağışlardan" sağlanmaktadır. Ancak bu iki kalemden sağlanacak toplam gelirin siyasi partilerin giderlerini karşılamada yetersiz kaldığı görülmektedir. Bu noktada siyasi partiler açısından yaşamsal önemi olan gelir kaynağı, "hazine yardımıdır" (Aydın, 2005).

Buna ilişkin olarak Adalet ve Kalkınma Partisi (AK PARTi)'nin 30.06.2011 tarihli Gelir-Gider Cetveli' incelendiğinde; partinin gider toplamı yaklaşık olarak 96.1 Milyon TL'dir. 2011 yılının seçim yılı olmasına bağlı olarak, bu giderlerin \%57,7'sinin parti teşkilatlarına yardımlar (55.5 Milyon TL) ve \%27'lik kısmının ise seçim giderleri (25.3 Milyon TL) olarak gerçekleştiği görülmektedir. Bunun yanında $\% 5,5^{\prime}$ lik sair giderler, $\% 3,8^{\prime}$ lik personel giderleri, \%2,4'lük basın yayın ve tanıtım giderleri ve $\% 3,6^{\prime}$ 'ık diğer giderler mevcuttur.

Partinin gelirleri incelendiğinde ise, toplam gelirlerin \%8,9'luk kısmı (18.2 Milyon TL) hazine yardımı dışında kalan diğer gelirlerden sağlanmıştır. Buradan da açıkça görülmektedir ki, hazine yardımlarının söz konusu olmadığı durumlarda siyasi partilerin elde ettikleri gelirlerle giderlerini karşılaması söz konusu değildir. AK PARTi'nin toplam gelirleri içerisinde hazine yardımının payı \%91.1 (186.5 Milyon TL) olarak gerçekleşmiştir.

Maliye Bakanlığı Bütçe ve Mali Kontrol Genel Müdürlüğü'nün açıkladığı rakamlara göre, 2011 yılında gerçekleşecek olan seçim dolayısıyla 2007 genel seçimlerinde barajı geçen 3 partiye toplamda 327.2 Milyon TL para aktarılmıştır. Bu tutarın, 186.5 Milyon TL'si Adalet ve Kalkınma Partisi'ne, 83.6 Milyon TL'si Cumhuriyet Halk Partisi (CHP)'ne ve 57.1 Milyon TL'si ise Milliyetçi Hareket Partisi (MHP)'ne aktarılmıştır ${ }^{2}$

Türkiye genelinde 2011 genel seçimlerine 14 siyasi parti katılmıştır. Bunlardan sadece 3 tanesine Hazine tarafından yardımın gerçekleştirilmiş olması, geriye kalan 11 partinin giderlerini karşılamada ciddi sıkıntılar içerisinde olduğunu açıkça göstermektedir. Seçmenlere yönelik hazırlanan siyasal kampanyaların düzenlenebilmesi için gerekli olan fonların finansmanında, hazine yardımı alamayan partiler, diğer gelir kaynaklarına yönelmektedirler. Bu durum, partileri, aday belirleme sürecinde hazine yardımı dışında kalan diğer gelir kaynaklarına yöneltmektedir. Bu noktada, adayların finansal olanakları bir seçim ön kriteri haline gelmektedir. Ayrıca, hazine yardımı alamayan ve finansal olanakları güçlü adaylara sahip olmayan partiler ise, kampanya harcamalarında ciddi kısıtlamalarla karşılaşmaktadırlar.

\section{ARAŞTIRMANIN AMACI VE KAPSAMI}

Araştırmanın amacl, 2011 Milletvekili Genel Seçimleri sürecinde İzmir ilinden aday gösterilen bireylerin finansal tercihlerinin belirlenmesidir. Çalışmanın amacı çerçevesinde İzmir İli'nde siyasi partilerden aday gösterilen 374 kişi çalışmanın anakütlesini oluşturmaktadır. Zaman, adayların seçim dönemi öncesi sürekli mobil olarak seçmenlerle iletişimde bulunması ve bazı siyasi partilerin İzmir îlinde herhangi bir irtibat bürosunun dahi olmayışı kısıtları dolayısıyla 54 milletvekili adayı ile görüşülmüş, elde edilen bulgular değerlendirilmiştir. Ulaşılan milletvekili aday sayısı çalışmanın amacı bakımından yeterli görülmüştür. Tablo 1'de adayların partilere yönelik dağılımları gösterilmektedir.

Tablo 1: Adayların Partilere Yönelik Dağılımları

\begin{tabular}{|l|c|c|c|}
\hline \multicolumn{1}{|c|}{ Parti } & Aday Sayısı & $\begin{array}{c}\text { Görüşülen } \\
\text { Aday } \\
\text { Sayısı }\end{array}$ & Yüzde \\
\hline AK PARTi & 26 & 8 & 14,8 \\
\hline DP & 26 & 3 & 9,3 \\
\hline CHP & 26 & 12 & 22,2 \\
\hline MP & 26 & 0 & 0 \\
\hline LDP & 26 & 0 & 0 \\
\hline SP & 26 & 6 & 11,1 \\
\hline HEPAR & 26 & 5 & 9,3 \\
\hline HAS PARTi & 26 & 1 & 1,9 \\
\hline MHP & 26 & 4 & 7,4 \\
\hline DYP & 26 & 0 & 0 \\
\hline TKP & 26 & 4 & 7,4 \\
\hline MMP & 26 & 0 & 0 \\
\hline BBP & 26 & 4 & 7,4 \\
\hline DSP & 26 & 3 & 5,6 \\
\hline BAĞIMSIZ & 10 & 2 & 3,7 \\
\hline TOPLAM & 374 & 54 & 100 \\
\hline
\end{tabular}

\section{ARAŞTIRMANIN VERILERI VE YÖNTEMI}

Çalışmada verilerin toplanmasında survey yöntemi ve anket tekniği kullanılmıştır. Soru formunun hazırlanmasında Tütek vd.(2010)'dan faydalanılmıştır. Hazırlanan soru formu dört bölümden oluşmaktadır. İlk olarak beşli Likert ölçeği ile hazırlanan on soru adayların harcamalara yönelik genel algılamalarını tanımlarken, ikinci bölüm soruları ise adayların kampanya harcamalarını seçilme olasılığının artması durumunda ne miktarda artırıp arttıramayacaklarını belirlemeye yöneliktir. Üçüncü bölümde ise senaryo tekniği kullanılarak adayların kampanya harcama- 
larına yönelik risk algılamaları ölçülmektedir. Soru formunun son bölümünde ise demografik bilgilere ilişkin sorular yöneltilmiştir.

Uygulama sonucu elde edilen veriler SPSS 16.0 paket programına aktarılmış, bulgulara ilişkin dağılımlarda tanımlayıcı istatistiklerden yararlanılmış olup, demografik değişkenler itibariyle ortaya çıkan farklılıklar Anova ve t testleriyle analiz edilmiştir.

\section{BULGULAR VE DEĞERLENDIRILMESi}

Araştırma sonucunda adaylara ilişkin demografik veriler Tablo 2'de gösterilmektedir.

Tablo 1'de görüleceği üzere araştırmaya katılan milletvekili adaylarının 34'ü 1. bölge, 20'si ise 2 . bölgeden seçime katılmaktadır. Örneklemin \%74,1'i erkek ve $\% 25.9^{\prime} u$ ise kadın adaylardan oluşmaktadır. Bu dağılım T.B.M.M. içerisindeki kadın $(\% 14,39)$ erkek $(\% 85,61)$ sayılarının dağılımına benzerlik göstermektedir. Örnekleme katılanların \%90.7'si 55 yaşın altındadır. Ayrıca \%20.4'ü bekar ve \% 79.6'sı evlidir. Örneklemin \%72.2'si üniversite veya daha üst bir mezuniyet derecesine sahiptir. Son olarak gelir dağılımı incelendiğinde; adayların \%48.1'i 3.000TL ve altı gelire sahipken, \%21.4'ü ise 6.000TL ve üzeri gelire sahiptir.
Tablo 2: Örneklemin Demografik Özellikleri

\begin{tabular}{|c|c|c|c|}
\hline & & Frekans & Yüzde \\
\hline \multirow{2}{*}{$\begin{array}{c}\text { Seçim } \\
\text { Bölgesi }\end{array}$} & 1.Bölge & 34 & 63 \\
\hline & 2.Bölge & 20 & 37 \\
\hline \multirow[b]{2}{*}{ Cinsiyet } & Kadın & 14 & 25,9 \\
\hline & Erkek & 40 & 74,1 \\
\hline \multirow{7}{*}{ Yaş } & $25-30$ & 8 & 14,8 \\
\hline & $31-36$ & 9 & 16,7 \\
\hline & $37-42$ & 6 & 11,2 \\
\hline & $43-48$ & 8 & 14,8 \\
\hline & $49-54$ & 17 & 31,5 \\
\hline & $55-60$ & 5 & 9,3 \\
\hline & 61 ve üstü & 1 & 1,9 \\
\hline \multirow{2}{*}{$\begin{array}{c}\text { Medeni } \\
\text { Hal }\end{array}$} & Bekar & 11 & 20,4 \\
\hline & Evli & 43 & 79,6 \\
\hline \multirow{5}{*}{$\begin{array}{l}\text { Eğitim } \\
\text { Durumu }\end{array}$} & İlköğretim & 6 & 11,1 \\
\hline & Lise & 8 & 14,8 \\
\hline & Yüksek Okul & 1 & 1,9 \\
\hline & Lisans & 14 & 25,9 \\
\hline & Lisans Üstü & 25 & 46,3 \\
\hline \multirow{8}{*}{$\begin{array}{l}\text { Aylık Gelir } \\
\text { (TL) }\end{array}$} & 1.500 ve altı & 10 & 18,5 \\
\hline & $1.501-3.000$ & 16 & 29,6 \\
\hline & $3.001-4.500$ & 2 & 3,7 \\
\hline & $4.501-6.000$ & 2 & 3,7 \\
\hline & $6.001-7.500$ & 5 & 9,3 \\
\hline & $7.501-9.000$ & 3 & 5,6 \\
\hline & 9.001 ve üstü & 8 & 14,8 \\
\hline & Cevapsız & 8 & 14,8 \\
\hline
\end{tabular}

Tablo 3: Milletvekili Adaylarının Finansal Kararlarını Etkileyen Değişkenlere Yönelik Bulgular

\begin{tabular}{|l|c|c|c|c|}
\hline & $\mathrm{N}$ & Ort. & $\sigma$ \\
\hline 1-Milletvekili seçilebilmek için yeterli finansal olanaklara sahibim. & 53 & 2,88 & 1,47 \\
\hline $\begin{array}{l}\text { 2-Adaylığım süresince ortaya çıkabilecek ek masraflara } \\
\text { katlanabileceğimi düşünüyorum. }\end{array}$ & 53 & 3,56 & 5,83 \\
\hline $\begin{array}{l}\text { 3-Kampanya harcamalarının siyasi partiler tarafından karşılanması } \\
\text { gerekmektedir. }\end{array}$ & 53 & 3,11 & 1,17 \\
\hline $\begin{array}{l}\text { 4-Adaylığım süresince yapacağım harcamalar nedeniyle gelecek } \\
\text { dönemlerde finansal sıkıntı yaşayacağımı düşünmüyorum. }\end{array}$ & 53 & 2,98 & 1,33 \\
\hline $\begin{array}{l}\text { 5-Milletvekili seçilememe durumunda adaylığım süresince } \\
\text { yaptığım harcamalardan pişmanlık duyarım. }\end{array}$ & 53 & 1,47 & 0,84 \\
\hline $\begin{array}{l}\text { 6-Adayların seçim dönemlerinde yüksek harcamalar yapması etik } \\
\text { değildir. }\end{array}$ & 53 & 4,15 & 0,96 \\
\hline $\begin{array}{l}\text { 7-Kampanya süresince en çok harcama yapan adayın kazanma } \\
\text { ihtimali yüksektir. }\end{array}$ & 54 & 1,92 & 1,07 \\
\hline 8-Partilerin kampanya bütçeleri hazine yardımı ile sınırlı olmalıdır. & 53 & 2,43 & 1,37 \\
\hline $\begin{array}{l}\text { 9-Aday adaylığı başvuru ücretleri ve aidatlar kampanya } \\
\text { harcamaları için yeterlidir. }\end{array}$ & 52 & 2,30 & 1,14 \\
\hline $\begin{array}{l}\text { 10-Türkiye'de seçilebilmek için katlanılan finansal yükler oldukça } \\
\text { yüksektir. }\end{array}$ & 53 & 3,94 & 1,09 \\
\hline
\end{tabular}

Milletvekili adaylarının seçim sürecinde verdikleri finansal kararları etkileyen değişkenlere yönelik bulgular Tablo 3'te yer almaktadır.

Tablo 3 içerisinde verilen tanımlayıcı istatistikler, kesinlikle katılmıyorum ile kesinlikle katılıyorum arasında değişen $5^{\prime}$ li likert tipi ölçek ile hazırlanan ifadelere aittir. Milletvekili adaylarının seçim süresince yapacakları harcamalar için yeterli bir finansal kaynağa sahip olup olmama durumuna yönelik sorulan soruya verilen cevapların ortalaması 2,88 olup, bu değer adayların seçilebilmek için yeterli kaynağa 
kısmen sahip olduklarını düşündüklerini ifade etmektedir. Adayların seçim süresince ortaya çıkabilecek ek masraflara katlanabilmesi üzerine yöneltilen soruya verilen ortalama değeri 3,56 olup, adayların seçim sürecinde ortaya çıkabilecek muhtemel ek masraflara katlanabileceği yönünde değerlendirilmiştir. Adaylara yöneltilen diğer bir ifade, kampanya harcamalarının siyasi partiler tarafından karşılanması yönündedir. Adayların bu ifadeye verdikleri yanıtların ortalaması 3,11'dir. Bu ise, adayların kampanya harcamalarının siyasi partiler (merkez) tarafından karşılanması gerekliliği ifadesine katıldıklarını göstermektedir. Adaylığı süresinde yaptığı harcamaların gelecek dönemde kendisini sıkıntı içerisine sokup sokmayacağının analiz edildiği 4. sorunun sonuçları incelendiğinde ise, adayların kısmen de olsa böyle bir sıkıntı yaşayabilecekleri yönünde cevaplar elde edilmiştir.

Milletvekili adaylarının seçim süresince yaptıkları harcamalardan dolayı gelecek dönemlerde pişmanlık duyup duymayacağına yönelik ifadeye verilen cevapların ortalaması 1,47'dir. Bu sonuç ise, adayların yaptıkları harcamalardan dolayı herhangi bir pişmanlık duymayacağını göstermektedir. Ayrıca adaylarla yapılan anket sürecinde, adayların çoğunluğunun bunun bir "gönüllülük" olduğunu belirtmesi de bu cevabı destekler niteliktedir. Seçim dönemlerinde yapılan yüksek harcamaların etik olup olmadığına yönelik soruya adayların hemen hemen tamamı katılmakta olup ( $x=4,15)$, adaylar bu tür yüksek harcamaları etik dışı görmektedir.

Adaylara yöneltilen bir diğer soru, "kampanya süresince en çok harcama yapan adayın seçilme şansı yüksektir" şeklindedir. Verilen ifadeye yönelik sonuçların ortalaması 1,92'dir. Bu sonuç ise, milletvekili seçilebilme intimalinin adaylar tarafından gerçekleştirilen harcama miktarı ile doğru orantılı olmadığını ifade etmektedir. Bunun nedeni olarak, seçmenlerin karar verme süreçlerinde ideoloji, parti bağımlılığı ya da lidere yönelik olumlu tutumların da etkisinin olduğu düşünülmektedir. Partilerin kampanya bütçelerinin hazine yardımı ile sınırlı olup olmamasına yönelik ifadeye ise adaylar kısmen katılmamaktadır. Bu durumun ise 2011 seçimlerinde yalnızca 3 partinin hazine yardımı alması ve geriye kalan partilerin ise kampanya harcamalarını otofinansman yolu ile sağlaması nedeniyle ortaya çıkabileceği düşünülmektedir.

Seçim harcamalarının finansmanının sağlanmasında aday adaylığı başvuru ücretleri ve aidatların yeterli olup olmadığına yönelik sorulan soruya yine adaylar kısmen katılmamaktadır. Özellikle meclis dışında bulunan partilerin daha düşük başvuru ücretleri ve aidatlar istemesi, kampanya harcamalarının ister istemez aday tarafından da desteklenmesini gerektirmektedir.

Milletvekili adaylarına yöneltilen son ifade ise, "Türkiye'de seçilebilmek için katlanılan finansal yükler oldukça yüksektir" şeklindedir. Bu ifadeye adayların verdiği yanıtların ortalaması 3,94 olup, adaylar seçilmek için katlandıkları finansal yüklerin oldukça yüksek olduğu düşüncesinde birleşmektedirler.

Seçim kampanyalarının finansmanı siyasi partilerin olduğu kadar adayların da katkılarıyla gerçekleşmektedir. Ancak hiçbir kampanyanın da sınırsız bir bütçesi söz konusu değildir. Her aday seçim döneminde araç giydirme, çeşitli mecralarda reklam vb. gibi harcamalar için kişisel bir bütçeye sahiptir. Tablo 4, adayların 2011 genel seçim kampanyası için planladıkları bütçeleri gösterilmektedir.

Tablo 4: Adayların Seçim Kampanyası için Planladığı Bütçe Miktarları

\begin{tabular}{|l|c|c|}
\hline & Frekans & Yüzde \\
\hline $25.000 T L$ ve altı & 35 & 64,8 \\
\hline $25.001-50.000$ & 12 & 22,2 \\
\hline $50.001-75.000$ & 4 & 7,4 \\
\hline $75.001-100.000$ & 1 & 1,9 \\
\hline 100.001TL ve üzeri & 2 & 3,7 \\
\hline TOPLAM & 54 & 100 \\
\hline
\end{tabular}

Tablo 4 incelediğinde, milletvekili adaylarının $\% 64,8^{\prime} i$ seçim harcamaları için kişisel bütçesini 25.000TL'nin altında, \%22,2'si 25.001TL ile 50.000TL arasında ve \%13'ü ise $50.001 T L$ ve üzerinde planlamaktadır. Bu tablodan kısaca adayların kişisel anlamda kampanya bütçelerini yüksek miktarlarda harcamaya olanak verecek şekilde planlamış olmadıkları görülmektedir.

Bireyler herhangi bir işlemin lehlerine sonuç vereceği ihtimali yükseldiğinde, işe yönelik alacakları kararlarda iki tür olasılığa sahiptirler. Bunlar, işlem için ya riskli olan bir karar vermek ya da riskli olmayan bir tercih yapmaktır. Bu durum itibariyle kampanya sürecinde adayın kazanma ihtimalinin yükseleceğini düşünmesi, adayın harcamalarında risk alan bir davranış göstermesine neden olabilecektir. Milletvekili adaylarının kazanma ihtimallerinin artması durumunda kampanya harcamalarını arttırıp arttıramayacaklarına yönelik sorulardan elde edilen bulgular Tablo 5'te gösterilmektedir. 
Tablo 5: Kazanma İhtimali ile Ek Fon Yaratma İlişkisi

\begin{tabular}{|l|c|c|c|c|c|c|c|}
\hline \multicolumn{9}{|c|}{} & \multicolumn{2}{c|}{$\% 25$} & \multicolumn{2}{c|}{$\% 50$} & \multicolumn{2}{c|}{$\% 75$} \\
\hline Kampanya Bütçesi & Frekans & Evet & Hayır & Evet & Hayır & Evet & Hayır \\
\hline 25.000TL ve altı & 35 & 4 & 31 & 7 & 28 & 10 & 25 \\
\hline 25.001TL-50.000TL & 12 & 1 & 10 & 3 & 8 & 3 & 8 \\
\hline 50.001TL-75.000TL & 4 & 1 & 3 & 1 & 3 & 1 & 3 \\
\hline 75.001TL-100.000TL & 1 & 1 & 0 & 1 & 0 & 1 & 0 \\
\hline 100.001TL ve üzeri & 2 & 0 & 2 & 0 & 2 & 0 & 2 \\
\hline
\end{tabular}

Milletvekili adaylarının seçim dönemlerinde ortaya koydukları çalışmaların sırası ile $\% 25, \% 50$ ve $\% 75$ olasılıkla kendilerini T.B.M.M'ye taşıyacaklarını düşündüklerinde kampanya harcamalarını arttırıp arttıramayacaklarına yönelik verilen ifadeler sonucunda; 25.000TL ve altı kampanya bütçesine sahip adayların kazanma intimalinin \%25 olması durumunda sadece \%11'i kampanya harcamalarını arttıracağını belirtmiştir. Kazanma ihtimalinin \%50 olması durumunda bu oran \%20'ye yükselirken, son olarak kazanma intimalinin \%75 olması durumunda ise adayların $\% 28,6$ 'sı kampanya harcamalarını arttıracaklarını ifade etmişlerdir. Bu durum, adayların kazanma ihtimalleri ile seçim harcamaları arasında bir doğru orantının mevcut olduğunu ve risk azaldıkça, buna bağlı olarak harcamaların artabileceğini göstermektedir.

25.001TL ile 50.000TL arasında kampanya bütçesine sahip adayların; kazanma ihtimallerinin \%25 olması durumunda \%8,3'ü kampanya harcamalarını arttıracağını belirtirken, kazanma ihtimallerinin sırasıyla $\% 50$ ve $\% 75$ olması durumunda ise adayların \%25'inin kampanya harcamalarını arttıracağı görülmektedir.

50.001TL ile 75.000TL arasında kampanya bütçesine sahip adayların \%75'i kazanma intimallerinin artması durumunda kampanya harcamalarında herhangi bir artış yapmayacakları görülmektedir. 75.001TL ve 100.000TL arasında kampanya bütçesine sahip tek aday ise her üç kazanma ihtimalinde de kampanya harcamalarını arttıracağını belirtirken, 100.001TL ve üzeri kampanya bütçesine sahip adayların ise her üç ihtimal doğrultusunda kampanya harcamalarında herhangi bir artış olmayacağı görülmektedir.

Milletvekili adaylarının kampanyalarının finansmanı her ne kadar kişisel bütçeleri ile doğru orantılı olsa da, bir kişinin iktidar partisi ya da yerel anlamda güçlü bir partiden aday olması, ortaya koyabileceği maddi imkanların sınırlarını da değiştirebilecektir. Bu nedenle adayların finansal tercihlerine yönelik bulguların adayın partisine göre yarattığı farklılıkların belirlenmesi tarafımızca önem arz eden bir konudur. Yapılan analizler sonucunda; adayların Türkiye'de se- çilebilmek için katlandıkları finansal yükler ve sahip olduğu finansal olanaklar açısından aday oldukları partilere göre farklılık ortaya çıkmaktadır. Bu farklııklara yönelik bulgular Tablo 6 ve Tablo 7'de gösterilmektedir.

Tablo 6: Adayların Sahip Olduğu Finansal Olanakların Partilere Göre Ortaya

\begin{tabular}{|l|c|c|c|c|}
\hline \multicolumn{1}{|c}{ Çıkan Farklılıkları } \\
\hline & $\mathrm{N}$ & Ort & $\mathrm{F}$ & $\mathrm{p}$ \\
\hline AK PARTi & 8 & 4,50 & & 0,005 \\
SP & 6 & 2,16 & & \\
\hline AK PARTi & 8 & 4,50 & & 0,000 \\
TKP & 4 & 1,25 & & \\
\hline AK PARTi & 8 & 4,50 & & 0,002 \\
HEPAR & 5 & 1,80 & & \\
\hline AK PARTi & 8 & 4,50 & & 0,000 \\
BBP & 4 & 1,25 & & \\
\hline AK PARTi & 8 & 4,50 & & 0,022 \\
Bağımsız & 2 & 1,50 & & \\
\hline CHP & 12 & 3,50 & & 0,017 \\
TKP & 4 & 1,25 & \multirow{5}{*}{6,955} & \\
\hline CHP & 12 & 3,50 & & 0,017 \\
BBP & 4 & 1,25 & & \\
\hline DP & 5 & 4,00 & & 0,010 \\
TKP & 4 & 1,25 & & \\
\hline DP & 5 & 4,00 & & 0,048 \\
HEPAR & 5 & 1,80 & & \\
\hline DP & 5 & 4,00 & & 0,010 \\
BBP & 4 & 1,25 & & \\
\hline & & &
\end{tabular}

Milletvekili adaylarının kampanya harcamaları için sahip oldukları finansal olanaklar adayların tabi oldukları partilere göre farklılık göstermektedir. Bu farklılığın ortaya çıkarılması için yapılan $F$ testi sonucunda AK PARTi ile TKP, SP, HEPAR, BBP ve Bağımsız adaylar arasında anlamlı bir farklılık ortaya çıkmaktadır. Farkın tanımlanması için yapılan Tukey HSD testi sonucunda AK PARTi'li milletvekili adaylarının TKP, SP, HEPAR, BBP ve Bağımsız adaylara göre oldukça yüksek düzeyde finansal olanaklara sahip olduğu görülmektedir. İktidar partisinin yaptığı yoğun kampanyanın bir sonucu olarak adayların da yüksek harcamalar yapması kaçınılmaz bir gerçektir. Diğer taraftan, diğer partilerin finansal olanakları hem merkezi hem de adayları açısından iktidar partisine nazaran daha düşük düzeydedir. 
Adayların sahip olduğu finansal olanaklar açısından ortaya çıkan bir diğer farklılık, CHP ile TKP ve BBP arasındadır. Farklıı̆̆ın nedenini ortaya çıkarmak için yapılan Tukey HSD testine göre CHP'li adaylar kendilerini finansal açıdan yeterli görürlerken $(\bar{x}=3,50)$, TKP'li ve BBP'li adaylar ise bu anlamda kendilerini finansal açıdan yeterli görmemektedirler $(\bar{x}=1,25)$.

Analiz sonucunda elde edilen son farklılığa ilişkin bulgu ise DP'li adaylar ile TKP, HEPAR, BBP'li adaylar arasındadır. Bu farklılığın nedeni incelendiğinde yine DP'li adayların finansal olanaklara yeterli düzeyde sahip olduklarını düşünmeleri ( $\bar{x}=4,00$ ) ve TKP, BBP, HEPAR'I adayların ise yeterli olanaklara sahip olmadığını düşünmeleridir $(\bar{x}=1,25)$.

Yukarıda belirtilen farklılıkların ortaya çıkmasında siyasi partilerin kampanya stratejileri arasındaki faklılıklar temel neden olarak görülmelidir. İktidar partisinden aday adayı olmanın maliyeti neredeyse diğer partilerin adaylarının toplam kampanya harcamalarına yakın bir rakama eş değer olmaktadır. Sonuç olarak oy seviyesi daha düşük olan partilerden aday olan kişiler, kendilerini iktidar partisinin kampanya harcamalarına rekabet edebilecek finansal olanaklara sahip görememektedirler.

Yapılan analizler sonucunda ulaşılan bir diğer farklılık ise, Türkiye'de seçilebilmek için katlanılan finansal yüklerin oldukça yüksek olmasına yöneliktir. Yapılan analiz sonucu elde edilen bulgular Tablo 7'de özetlenmiştir.

Tablo 7: Adayların Katlandıkları Finansal Yüklerin Partilere Göre İncelenmesi

\begin{tabular}{|c|c|c|c|c|}
\hline & & & & \\
\hline & $\mathrm{N}$ & Ort & $\mathrm{F}$ & $\mathrm{p}$ \\
\hline AK PARTI & 8 & 2,37 & & 0,000 \\
\hline CHP & 12 & 4,25 & & \\
\hline AK PARTI & 8 & 2,37 & & 0,002 \\
\hline DSP & 3 & 4,66 & & \\
\hline AK PARTI & 8 & 2,37 & & 0,001 \\
\hline SP & 6 & 4,33 & & \\
\hline AK PARTI & 8 & 2,37 & & 0,000 \\
\hline TKP & 4 & 4,75 & & \\
\hline AK PARTI & 8 & 2,37 & & 0,000 \\
\hline HEPAR & 5 & 4,80 & & \\
\hline AK PARTI & 8 & 2,37 & & 0,030 \\
\hline BBP & 4 & 4,00 & & \\
\hline AK PARTI & 8 & 2,37 & & 0,027 \\
\hline Bağımsız & 2 & 4,50 & 7,551 & \\
\hline $\mathrm{CHP}$ & 12 & 4,25 & & 0,010 \\
\hline MHP & 3 & 2,33 & & \\
\hline MHP & 3 & 2,33 & & 0,015 \\
\hline DSP & 3 & 4,66 & & \\
\hline MHP & 3 & 2,33 & & 0,016 \\
\hline SP & 6 & 4,33 & & \\
\hline MHP & 3 & 2,33 & & 0,005 \\
\hline TKP & 4 & 4,75 & & \\
\hline MHP & 3 & 2,33 & & 0,002 \\
\hline HEPAR & 5 & 4,80 & & \\
\hline
\end{tabular}

Türkiye'de seçilebilmek için katlanılan finansal yüklerin oldukça yüksek olması partilerin adaylarına göre aralarında anlamlı bir farklılık yaratmaktadır $(F=7,551 ; p=0,000)$. Bu farklılık incelendiğinde; $A K$ PARTi'li adaylar ile CHP'li $(p=0,000)$, DSP'li $(p=0,002)$,

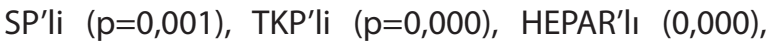
BBP'li $(p=0,030)$ ve Bağımsız adaylar $(p=0,027)$ arasında anlamlı bir farklılık bulunmaktadır. Bu farklılığın incelenmesi için yapılan Tukey HSD testinin sonucunda, CHP, DSP, SP, TKP, HEPAR, BBP ve Bağımsız adaylar Türkiye'de seçilebilmek için katlanılan finansal yükleri benzer şekilde oldukça yüksek olarak tanımlarken, AK PARTi'li adaylar ise katlanılan bu yükleri oldukça yüksek görmemektedirler $(\bar{x}=2,37)$.

Ortaya çıkan bir diğer farklılık, CHP ile MHP'li adaylar arasındadır $(p=0,010)$. Bu farklılığın içeriği incelendiğinde CHP'li adayların seçilebilmek için katlanılan finansal yükleri oldukça yüksek seviyelerde görmesi $(\bar{x}=4,25)$ ve MHP'li adayların ise bu yükleri oldukça yüksek görmemesinden $(\bar{x}=2,33)$ kaynaklandığı görülmektedir.

Analizler sonucu elde edilen son farklılık ise MHP'li adaylar ile SP'li adaylar $(p=0,016)$, DSP'li adaylar $(p=0,015)$, TKP'li adaylar $(p=0,005)$ ve HEPAR'lı adaylar $(p=0,002)$ arasındadır. Elde edilen fark incelendiğinde, MHP'li adayların seçilebilmek için gereken finansal yüklere yönelik algılamalarının sayılan partilerin adaylarının algılamalarından daha düşük seviyede olduğu görülmektedir.

Milletvekili adaylarının seçim kampanyalarının finansmanını sağlamak için yaptıkları harcamalarda risk alan ya da almayan bir davranış içerisinde olup olmadıklarını belirleyebilmek amacıyla adaylara örnek bir senaryo aktarılmış ve "Bu kişinin yerinde siz olsaydınız, 100.000TL'lik kampanya harcaması için finansal tercihleriniz nasıl olurdu?" sorusu yöneltilmiştir. Adaylar, örnek olaya yönelik 5 farklı cevap seçeneğine sahiptirler. Bu seçenekler; "1-harcamaların finansmanı için sahip olduğu evini satmak, 2-arabasını satmak ve kalanı için kredi çekmek, 3-tamamını kredi çekmek, 4-seçim harcamalarından vazgeçmek ve 5-diğer ${ }^{3 \prime \prime}$ şeklindedir. Adaylardan bu ifadelere 4 farklı koşul altında cevap vermeleri istenmiştir. Risk düzeyi olarak; aday için en düşük risk, güçlü bir partinin ilk sıralarından aday gösterilmek, en yüksek risk ise, zayıf bir partinin son sıralarından aday gösterilmektir. Milletvekili adaylarının, senaryoya ilişkin cevapları Tablo 8'de gösterilmektedir.

Adaylara yöneltilen senaryo (Tütek vd., 2010) ise şu şekildedir; 
"Yalçın Bey (Yasemin Hanım) 40 yaşında, bir özel sektör kuruluşunda üst düzey yönetici olarak çalışmaktadır. Eşi Yasemin Hanım (Yalçın Bey) ise 40 yaşında ve devlet memurudur. Ailenin 15 ve 18 yaşlarında özel okulda okuyan iki çocuğu bulunmaktadır. Ailenin 84.000TL yıllık gelirinin yanında hâlihazırda oturmak- ta olduğu 200.000TL değerinde kendilerine ait bir ev, 40.000TL değerinde bir araba ve bankalar nezdinde yüksek bir kredibilitesi mevcuttur. 2011 genel seçimlerinde X partisinden Izmir'den aday adayı olan Yalçın Bey (Yasemin Hanım), aday seçilmesi durumunda, ortalama 100.000TL bir seçim harcamasını öngörmektedir."

Tablo 8: Örnek Senaryo ve Adayların Finansal Tercihleri

\begin{tabular}{|c|c|c|c|c|c|c|c|c|c|}
\hline \multirow[t]{2}{*}{ X PARTISI } & \multirow{2}{*}{$\begin{array}{c}\begin{array}{c}\text { Evimi } \\
\text { Satarım }\end{array} \\
\mathrm{N}\end{array}$} & \multicolumn{2}{|c|}{$\begin{array}{l}\text { Arabamı Satar } \\
\text { ve Kalanı için } \\
\text { Kredi Çekerim }\end{array}$} & \multicolumn{2}{|c|}{$\begin{array}{l}\text { Tamamını } \\
\text { Kredi } \\
\text { Çekerim }\end{array}$} & \multicolumn{2}{|c|}{$\begin{array}{l}\text { Seçim Har. } \\
\text { Vazgeçerim }\end{array}$} & \multicolumn{2}{|c|}{ Diğer } \\
\hline & & $\mathrm{N}$ & $\%$ & $\mathrm{~N}$ & $\%$ & $\mathrm{~N}$ & $\%$ & $\mathrm{~N}$ & $\%$ \\
\hline \multicolumn{10}{|l|}{ GÜÇLÜ PARTI } \\
\hline İlk Sıralardan & 0 & 8 & 14,8 & 16 & 29,6 & 15 & 27,8 & 14 & 25,9 \\
\hline Son Sıralardan & 0 & 6 & 11,1 & 8 & 14,8 & 30 & 55,6 & 9 & 16,7 \\
\hline \multicolumn{10}{|l|}{ ZAYIF PARTI } \\
\hline İlk Sıralardan & 0 & 6 & 11,1 & 6 & 11,1 & 32 & 59,3 & 9 & 16,7 \\
\hline Son Sıralardan & 0 & 4 & 7,4 & 5 & 9,3 & 38 & 70,4 & 6 & 11,1 \\
\hline
\end{tabular}

Anket gerçekleştirilen 54 Milletvekili adayından 53 tanesinin cevaplandırdığı senaryoya ilişkin sonuçlar incelendiğinde; öncelikle hiçbir adayın, kampanya finansmanı için riskli görülen "evini satma" fikri kendilerince makul bir seçenek olarak değerlendirilmemektedir. Güçlü bir partinin ilk sırasından ya da zayıf bir partinin son sırasından aday olmak arasında herhangi bir farklıık olmaksızın kampanya finansmanı için "ev" gibi değerli bir maddi varlığın elden çıkarılması büyük bir risk unsuru olarak değerlendirilmektedir. Maslow'un İhtiyaçlar Hiyerarşisi göz önünde bulundurulduğunda, "ev" kişilerin temel ihtiyaçlarından biri olan "barınma" gereksinimini karşılamaktadır. Bu nedenle, seçim sonuçlarına yönelik kesin bir durumun söz konusu olmaması, bireyleri temel intiyaçlarını gidermede kullandığı araçların bir fon kaynağı olarak görülmesini engellemektedir.

Adayların güçlü bir partinin ilk sıralarından aday olması durumunda 100.000TL değerinde bir kampanya harcamasının finansmanında, $\% 14,8$ 'i "arabamı satarım ve kalanını kredi çekerim" ifadesini tercih etmekte, \%29,6'sı ise "tamamını kredi çekerim" şeklinde bir tercih yapmaktadır. Adayların \%27,8'si, senaryoda bulunan kişinin 100.000TL değerinde bir harcamayı yapmasını uygun görmemekte ve "seçim harcamalarından vazgeçerim" seçeneğini tercih ettikleri görülmektedir, geriye kalan $\% 25,9^{\prime}$ luk kısım ise, diğer seçeneğini tercih etmişlerdir. Senaryoda verilen kişinin güçlü bir partinin son sıralarından aday olması koşulunda; adayların \%11,1'i "arabamı satarım ve kaIanını kredi çekerim" ifadesini tercih ederken, \%16,7'si "tamamını kredi çekerim" ifadesini tercih etmektedir. Adayların \%55,6'sı "seçim harcamalarından vazgeçerim" seçeneğini tercih ederken geriye kalan \%16,7'lik kısım ise, "diğer" finansman tercihlerini belirtmişlerdir.
Senaryoda bahsedilen kişinin zayıf bir partinin ilk sıralarından aday olması durumunda çalışmaya katılan adayların \%11,1'i "arabamı satarım ve kalanını kredi çekerim" ifadesini tercih ederken, yine \%11,1'lik kısım "tamamını kredi çekerim" ifadesini tercih etmektedir. Adayların \%59,3'ü seçim harcamalarından vazgeçerken, geriye kalan \%16,7'lik kısım ise "diğer" seçeneğini tercih etmişlerdir. Milletvekili adayının zayıf bir partinin son sıralarından aday gösterilmesi durumuna yönelik olarak çalışmaya katılan adayların \%70,4'ü seçim harcamalarından vazgeçmekte, geriye kalan kısım ise, bu harcama tutarını diğer finansman tercihleriyle karşılamışlardır.

Yukarıdaki ifadeler her ne kadar bir örnek olayla ilgili adayların yorumlarını tanımlasa da, 100.000TL değerinde bir kampanya harcaması, çalışmaya katılan adaylar tarafından yüksek bir miktar olarak değerlendirilmektedir. Bu durum her ne kadar adayın güçlü bir partinin ilk sıralarında bulunması ile zayıf bir partinin son sırasında bulunması arasında farklılık gösterse de, adaylar temelde riskli bir finansal tercih yapmak için kazanma ihtimallerinin de yüksek olmasını istemektedirler. Bu durumu doğrulamak için tablodan seçim harcamalarından vazgeçme ifadesinin güçlü bir partinin ilk sıralarından aday olma ile zayıf bir partinin son sıralarından aday olma ifadelerine verilen cevapların yüzdelerine bakmak yeterli olacaktır.

\section{SONUÇ}

Siyasi partiler, özellikle seçim dönemlerinde, seçim kampanyalarının finansmanı ve seçim arası dönemlerde de faaliyetlerinin sürekliliği için gelir kaynaklarına intiyaç duymaktadırlar. Siyasi partiler, bu kaynakları öncelikle topladıkları aidatlar ve bağışlarla 
karşılamaya çalışmaktadırlar. Ancak Türkiye'deki siyasi rekabet olgusunun artış trendi içerisinde bulunduğu günümüz koşullarında, bu sayılan finansman kaynaklarının siyasi partilerin giderlerini karşılamada yetersiz kaldıkları görülmektedir.

Siyasi partilerin seçim kampanyalarının ve diğer giderlerinin karşılanması noktasında toplanan aidat ve bağışların yetersiz kalması, "devletçe yapılan yardımlar"ın siyasi partiler açısından hayati derecede önem arz etmesine sebep olmaktadır. Devletin siyasi partilere yardım etmesinin temel nedeni, siyasi partilerin finansman sorunlarının çözümü noktasında, belirli kişi yada grupların etkisi altında kalmaması olarak görülebilir. Fakat Türkiye'deki siyasi konjonktürün oluşturduğu bir netice olarak, sadece üç siyasi partinin devlet yardımlarından faydalanması, geriye kalan siyasi partilerin, finansman sorunlarının çözümünde alternatif yollar aramalarına yönelmelerine temel neden olarak görülmektedir.

Başta devlet yardımı almayan siyasi partiler olmak üzere, tüm siyasi partilerin, seçim kampanyalarının finansmanı noktasında, adayların finansal olanaklarını da bir seçim kriteri haline getirdikleri görülmektedir. Bu durum, kampanya finansmanının yükünün partilerle birlikte adaylar tarafından karşılanmasına sebep olmaktadır. Adayların, seçilebilmek için katlandıkları finansal yüklerin oldukça yüksek olmasına yönelik algıları da, bu olguyu doğrular niteliktedir.
Çalışmaya katılan milletvekili adaylarının \%65 gibi büyük bir çoğunluğunun 25.000TL ve altında kişisel kampanya bütçesine sahip olduğu görülmektedir. Bu adaylar, seçim dönemlerinde özellikle yüksek harcamalar yapılmasının etik olmadığını ve kampanya sürecinde yüksek harcamalar yapabilen bir adayın da kazanma ihtimalinde herhangi bir artış olmayacağını düşünmektedirler. Ayrıca adayların büyük bir kısmı, siyasi rekabet ortamının daha adil bir şekilde sürebilmesi için hazine yardımının yalnızca 3 parti arasında paylaşılması yerine, bir önceki seçimlerde alınan oy oranları doğrultusunda seçime katılacak tüm partiler arasında paylaştııı masını istemektedirler.

Adaylara uygulanan senaryonun bulguları doğrultusunda, milletvekili adayları, seçim kampanyalarının finansmanı kararlarını alırken, siyasi partinin güçlü ya da zayıf bir parti olması ve ayrıca adayın parti içerisindeki seçim sırası, kampanya bütçelerinin oluşturulması aşamasında etkili bir değişken olarak değerlendirilmiştir.

Milletvekili adaylarını örneklem olarak alan çaısşmaların sayısı kısıtlı olmakla beraber; "seçim ekonomisi" kavramının yoğun olarak kullanıldığı ve siyasi partilerin gelir ve giderlerindeki ciddi artışların meydana getireceği "seçim endüstrisi", mutlak olarak araştırılmaya ihtiyaç duymaktadır. Dolayısıyla bu alanı derinlemesine inceleyecek yeni çalışmaların eklenmesi gerekliliği tarafımızca düşünülmektedir. 


\section{SON NOTLAR}

${ }^{1}$ http://www.akparti.org.tr/site/akparti/gelir-gider, Erişim Tarihi: 22.01.2012.

${ }^{2}$ http://hurarsiv.hurriyet.com.tr/goster/printnews. aspx?DocID=18011555, Erişim Tarihi: 22.01.2012.

3 "Diğer" seçeneği ile ifade edilmek istenen finansman şekilleri, adaylarla yapılan görüşmeler esnasında, adayların belirtilen 4 seçenek haricindeki görüşlerini kapsamaktadır. Bu kapsamda finansman şekilleri 4 ana başlık altında toplanmaktadır. Bunlar; "eş-dosta dayalı faizsiz finansman modeli", "seçmenlerden doğrudan maddi destek", "sponsorluk (hibe)" ve son olarak "gelirine göre harcama modeli" dir.

\section{KAYNAKLAR}

Aydın, M. (2005) “Türkiye'de Siyasal Partilere Devlet Yardımı" Ankara Üniversitesi Hukuk Fakültesi Dergisi, 54(4):235-265.

Bolak, M. (2004) Risk ve Yönetimi İstanbul, Birsen Yayınevi.

Fisher, J. ve Eisenstadt, T. (2004) "Comparative Party Finance: What is to be Done?" Party Politics, 10(6):619-626.

Özyavuz, T. (2007) “Türkiye'de Siyasetin Finansmanı" Yayınlanmamış Doktora Tezi, Marmara Üniversitesi, İstanbul, Sosyal Bilimler Enstitüsü.

Pinto-Duschinsky, Michael. (2002) "Financing Politics: A Globel View” Journal Of Democracy, 13(4).

Tütek, H., Aydoğan, B., Tunç, G. ve Vardar, G. (2010) "Finansal Risk Algılamalarında Cinsiyet Farklılığının Etkisi” İktisat Isletme ve Finans, 25(292):4770.

Adalet ve Kalkınma Partisi, (2012) http://www. akparti.org.tr/site/akparti/gelir-gider, (22.01.2012).

HÜRRIYYT, (2012) http://hurarsiv.hurriyet.com.tr/ goster/printnews.aspx?DocID=18011555, (22.01.2012).

Mevzuat Bilgi Sistemi, (2011) http://mevzuat. basbakanlik.gov.tr/Metin.Aspx?MevzuatKod=1.5.2820\& sourceXmlSearch=\&MevzuatIliski=0, (14.12.2011). 